\title{
单克隆抗体的出现与发展
}

\author{
马雪璟 ${ }^{1 \dagger}$ ，李润涵 ${ }^{1 \dagger}$, 侯百东 ${ }^{1,2 *}$ \\ 1. 中国科学院大学生命科学学院, 北京 100049 ; \\ 2. 中国科学院生物物理研究所感染与免疫重点实验室, 北京 100101 \\ $\dagger$ 同等贡献 \\ * 联系人, E-mail: baidong_hou@ibp.ac.cn
}

1975 年, 免疫学家 Georges Kohler 和 César Milstein ${ }^{[1]}$ 将免疫过后的小鼠脾细胞与骨髓瘤细胞融合, 形成的杂交 瘤细胞既可产生抗体, 又可无限增殖, 从而创立了具有划 时代意义的杂交瘤技术 (hybridoma technology). 他们也因 此获得了 1984 年诺贝尔生理学或医学奖. 从此, 人们可通 过细胞工程在体外定向制备并分离出已知抗原特异性的 单克隆抗体(monoclonal antibody).

\section{1 单克隆抗体的发现史}

抗体由 B 淋巴细胞产生, 可以特异性结合病原抗原并 阻断病原侵染. 抗体的发现源于抗毒素血清. 1890 年, von Behring 和 Kitasato ${ }^{[2]}$ 发现, 被白喉或破伤风毒素免疫的动 物血清中具有中和毒素的物质, 他们引入“抗体”一词来泛 指抗毒素物质. 在医学实践中, 抗血清一直被用于传染病 的被动免疫疗法或者检测工具. 然而, 由于血清抗体的多 克隆性及效价不稳定, 这些方法的效果不一, 还常受到过 敏反应和血液传播病原体风险增加等问题的限制.

杂交瘤技术的发展赋予了抗体在临床应用中划时代 的意义. 与多克隆抗血清相比, 单克隆抗体识别抗原的高 度特异性大大降低了非特异的交叉反应. 单克隆抗体可以 发挥的生物学功能主要有 ${ }^{[3]}$ : (1) 中和抗原作用; (2) 调理 细胞吞噬作用; (3) 介导细胞毒作用 (antibody-dependent cellular cytotoxicity, ADCC); (4) 激活补体作用. 但依据识 别抗原特点及自身性质的不同, 单克隆抗体发挥作用的主 要机制有明显差异.

杂交瘤技术的基础是细胞融合技术. 1958 年, 日本学 者冈田善雄(Okada)发现仙台病毒具有触发细胞融合的效 应. 1974 年, 加拿大学者高国楠创立了聚乙二醇(PEG)化学 融合法. Kohler 和 Milstein 在这些技术基础上发明了杂交 瘤技术. 这个方法克服了无法在体外连续培养原代 B 淋巴 细胞的障碍, 使其获得了持续增殖的能力. 实现此技术的 另一关键是利用缺乏次黄嘌呤磷酸核糖基转移酶 (hypoxanthine guanine phosphoribosyltransferase, HPRT)的 骨髓瘤细胞系作为融合细胞对象. 这种突变骨髓瘤细胞在 HAT 选择性培养基中会发生调亡, 而被融合的正常免疫细

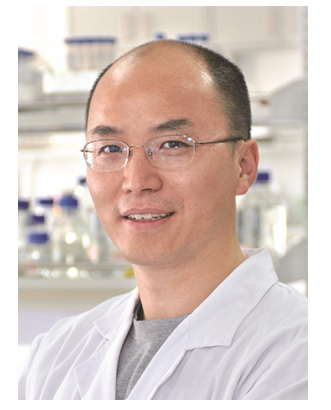

侯它东医学博士。中国科学 院生物物理研究所感染与免疫重点 实验室研究员, 博士生导师。研究 专注于抗体反应机理、 $\mathrm{B}$ 细胞免疫 和新型疫苗设计。研究成果系统性 揭示了 $\mathrm{B}$ 细胞抗原呈递功能在启动 抗病毒免疫反应中的重要功能, 对 创新疫苗设计将产生深远影响。

胞提供的 HPRT 可以使杂交瘤细胞在 HAT 培养基中存活, 故可以被篮选出来 ${ }^{[4]}$. 然后, 通过检测培养上清抗体, 可 以篮查出分泌抗原特异性单克隆抗体的杂交瘤细胞. 杂交 瘤技术的问世为淋巴细胞的克隆选择学说提供了强有力 的证据, 人们可以获得大量对单一抗原决定簇具有特异性 的纯化抗体, 这不仅解释了抗体产生的生物学问题, 也是 抗体生产的重大技术革命.

\section{2 单克隆抗体技术的发展}

自小鼠杂交瘤技术诞生以来, 单克隆抗体技术在过去 45 年间取得了长足的发展. 其中, 最显著的是多种各具特 色的抗体篮选技术的出现，为制备单克隆抗体提供了更多 的选择. 此外, 强烈的临床需求还催动了更高效的以人源 抗体为目标的单克隆技术的发展. 以下重点对这两个方向 进行介绍.

\section{1 抗体篮选技术的发展}

\subsection{1噬菌体展示技术}

噬菌体展示技术作为第一种可以高通量篮选对特定 病原体反应抗体的创新方法, 其主要技术流程包括: 从被 免疫或感染后的人体外周血单个核细胞(peripheral blood mononuclear cell, PBMC) 提取细胞总 RNA, 并反转录成 cDNA; 通过聚合酶链式反应 (polymerase chain reaction, $\mathrm{PCR})$ 扩增抗体重链可变区 $(\mathrm{VH})$ 和轻链可变区 $(\mathrm{VL})$ 基因片 
段, 随后将扩增的基因片段随机克隆形成组合文库; 将组 合文库导人丝状噬菌体(filamentous bacteriophage)与外膜 蛋白融合表达; 用固相化抗原直接、高效地篮选出表达特 异性好、亲和力强的抗体基因序列 ${ }^{[5]}$, 经体外加工形成全 人源抗体. 这个技术为抗体定向演化提供了全新策略, 从 根本上改变了传统杂交瘤技术制备流程, 一次篮选可获得 针对同一抗原不同表位的多种抗体, 缩短了实验周期并增 加了稳定性. 因此, 噬菌体展示技术于 2018 年被授予诺贝 尔化学奖 ${ }^{[6,7]}$. 但该技术也有明显缺点: 它对抗体蛋白的修 饰和折叠与人体细胞差别很大, 一定程度上影响了抗体的 亲和力 ${ }^{[8]}$. 因此, 噬菌体展示技术获得的抗体往往还需要 人工优化.

\section{1 .2 酵母展示技术}

酵母展示技术实现了从原核表达系统到真核表达系 统的进步. 酵母菌具有折叠酶、分子伴侣、内质网等, 在 蛋白质的折叠和分泌机制方面与高等哺乳动物相似, 基于 此建立起来的酵母表面展示技术可用于展示糖基化和二 硫键异构化等修饰的真核生物蛋白质, 有助于提高展示抗 体的稳定性和抗原结合能力. 并且, 利用流式细胞技术还 能对表达抗体的酵母颗粒进行分选, 达到高效、快速的篮 选和分离 ${ }^{[9]}$. 不过酵母的蛋白质修饰系统与人体依然有不 小的差异, 这对抗体功能仍存在一定影响 ${ }^{[10]}$.

\subsection{3 哺乳动物细胞展示技术}

中国仓鼠卵巢(Chinese hamster ovary, CHO)细胞是 目前用于真核基因表达的最成功的哺乳动物细胞, 在生 物工程上被广泛应用. 与噬菌体展示技术相比, 外源蛋白 更易在 CHO 细胞中合成并分泌到培养基; 重组蛋白能够 正确折叠、修饰、组装多亚基蛋白, 并且其理化性质、生 物学性质几乎与天然蛋白相似 ${ }^{[11]}$, 这在生物技术的发展 中具有很高的应用价值. 但外源基因在 $\mathrm{CHO}$ 表达系统中 的表达效率比在酵母展示系统中低且重组蛋白的生产成 本较高.

\subsection{4 核糖体展示技术}

核糖体展示技术由 Plückthun 实验室 ${ }^{[12]}$ 于 1997 年建立. 该技术通过 PCR 扩增淋巴细胞 CDNA 中的 VH 和 VL 基因 并引人体外表达元件方式构建文库, 然后在体外无细胞体 系中转录和翻译. 由于构建模板时 $3^{\prime}$ 端序列不含有终止密 码子, 因此体外翻译时核糖体停留于 mRNA 的 3'端, 使文 库基因的翻译产物展示在核糖体表面, 形成“蛋白质-核糖 体-mRNA"三元复合物. 最后用靶抗原反复篮选复合物、分 离 mRNA、逆转录富集目的基因 ${ }^{[13]}$, 从而获得特异性的单 克隆抗体序列. 与其他展示技术相比, 核糖体展示具有建 库简单、库容量大、分子多样性强、笁选方法简便、无须 选择压力, 还可通过引人突变和重组技术来提高靶标蛋白 的亲和力等优点, 是一种䇻选大型文库和进化抗体强有力 的方法. 如何进一步提高该系统的稳定性, 防止 mRNA 降 解, 则是该技术需要解决的关键问题.

\subsection{5 单细胞抗体基因扩增技术}

2008 年, Tiller 等人 ${ }^{[14]}$ 发明了一种从人外周血单个核 细胞快速制备单克隆抗体的方法. 其主要过程包括: 经流 式分选出抗原特异性单个 B 细胞, 单细胞 RT-PCR 与巢式 PCR 组合获取抗体重链和轻链的可变区基因信息, 将这些 基因克隆并在真核系统中表达. 单个 $\mathrm{B}$ 细胞的分离可以分 别通过“随机分选”或者“抗原特异性分选”两种途径进行 ${ }^{[14]}$. “随机选择”的主要方法有基于显微操作的细胞分选、流式 细胞分选技术等. “抗原特异性分选”的主要方法有抗原包 被的磁珠分离、苂光包被的抗原多参数流式细胞分选等. 此外, 近年来快速发展的单细胞测序技术使得研究人员能 够更低成本、更大规模地获得 $\mathrm{B}$ 细胞抗体基因. 同时, 细 胞微阵列芯片、显微雕刻技术 ${ }^{[15]}$ 和免疫斑点阵列芯片技 术 ${ }^{[16]}$ 也为高通量篮选单克隆抗体分泌细胞提供了条件. 与 各种抗体展示技术相比，单细胞抗体基因扩增技术能快 速、直接地获得人源抗体, 特别适合在突发传染病等情况 下发现有保护性的单克隆抗体.

\section{2 人源抗体技术的发展}

\subsection{1 嵌合抗体和人源化抗体}

由于通过小鼠杂交瘤技术制备的单克隆抗体是非人 源性的, 应用于人体不可避免地会引起人抗鼠抗体反应, 导致药物疗效降低, 或者引起过敏反应, 甚至威胁生命, 限制了单克隆抗体的临床应用 ${ }^{[17]}$. 为了克服这种缺陷, 20 世纪 80 年代中期, 研究者们寻求以基因工程技术对鼠源 性单克隆抗体进行改造优化，尝试对其进行人源化处理. 如将鼠源抗体可变区与人抗体恒定区拼接而形成“嵌合抗 体”, 或将鼠抗体可变区的互补决定区 (complementarity determining region, CDR) 与人抗体的互补决定区互换构成 “人源化抗体”, [18]. “嵌合抗体”的人源程度可达 $60 \%$, “人源 化抗体”可达 90\% 95\%. 这虽然在极大程度上保持亲本抗 体的特异性和亲和力, 但仍不是真正意义上的人源抗体 ${ }^{[5]}$, 仍无法完全避免进人人体后发生排斥反应或超敏反应.

\subsection{2 抗体基因人源化小鼠}

虽然各种抗体展示与篮选技术为制备人源单克隆抗 体提供了选择, 但是由于展示文库多样性不足或者抗原使 用等方面因素的限制, 获得理想抗体特别是高亲和力单克 隆抗体的效率仍然偏低. 直接由人 $\mathrm{B}$ 细胞构建抗体基因人 源化小鼠, 并通过自然篮选过程产生高亲和力人源抗体是 正在发展中的技术变革, 有望成为最具优势的抗体药物研 发平台. 该技术需要将小鼠抗体基因替换成相应人抗体基 因, 并且通过正常的抗体基因重排与克隆选择过程发育出 表达人源抗体的 B 细胞. 目前, 构建这种人源化小鼠的基 本方法是 ${ }^{[19]}$ 在鼠胚胎干细胞 (embryonic stem cell, ESC)中 进行同源重组使得鼠原有抗体基因缺失, 破坏其免疫系统, 再通过显微注射、逆转录病毒载体、酵母人工染色体系统 或者精子介导外源 DNA 转移等技术将重建的人源抗体肧 
系基因位点转人小鼠体内, 最终由杂交瘤技术或者抗体库 技术篮选出靶向的单克隆抗体. HuMAb-Mouse 与 XenoMouse 是目前最为成熟的转基因小鼠技术平台 ${ }^{[20]}$. 由 于人源化小鼠的抗体是在体内产生, 经历正常发育和成熟 过程, 其产生的抗体相对于其他技术具有较高的靶结合亲 和力. 但是, 该技术尚存在不足之处, 包括由于仅导人部 分人源基因引起的抗体多样性低, 对小分子化合物免疫原 性较弱, 不适合针对生物毒素等对机体有害的人源抗体的 制备以及所制备的抗体含有鼠糖基化修饰等 ${ }^{[21]}$.

\section{3 单克隆抗体药物的发展}

自 1986 年全球首个单克隆抗体药物上市以来, 美国 食品和药物管理局(Food and Drug Administration, FDA)共 批准了 79 种单抗药物 ${ }^{[22]}$. 在发展过程中, 单克隆抗体药物 经历了鼠源性抗体、嵌合抗体、人源化抗体、全人源抗体 四个阶段. 其应用范围也扩增到对肿瘤、自身免疫病和感 染等疾病的治疗中.

\section{1 单克隆抗体药物的人源化过程}

OKT3 是鼠源性单抗, 其靶点为 $\mathrm{T}$ 细胞表面的 $\mathrm{CD} 3$ 分 子, 被认为可以干扰 $\mathrm{T}$ 细胞的活化. 但是, 注射 OKT3 后却 引起类流感症状、肺水肿、中枢神经系统并发症等副作用. 这与诱发 IL-2、 $\gamma$-干扰素、TNF 等炎性因子急性释放的细 胞因子风暴有关, 因此治疗效果并不理想 ${ }^{[23]}$, 使得单抗药 物的市场发展一度陷人低潮 ${ }^{[24]}$. 直到 1997 年, 另一个被用 于治疗 B 细胞淋巴瘤的单克隆抗体药物利妥昔(Rituximab) 上市 ${ }^{[25]}$. 利妥昔是一种由鼠源抗体可变区与人抗体恒定区 拼接而形成 “嵌合抗体”, 其靶点为 B 细胞表面的跨膜蛋白 CD20, 后者也表达于 B 细胞来源的淋巴瘤、白血病等肿瘤 细胞以及参与免疫疾病和炎症疾病的 $\mathrm{B}$ 细胞中 ${ }^{[26]}$, 因此成 为治疗淋巴癌、白血病和某些自身免疫病的靶点. 利妥昔 单抗的上市和良好的临床疗效改善了单克隆抗体产业发 展低迷的态势.

1998 年, 用于预防感染呼吸道合胞病毒(respiratory syncytial virus, RSV)引起高危婴儿严重下呼吸道感染的单 克隆抗体帕利珠(Palivizumab)上市 ${ }^{[18]}$. 帕利珠是将鼠抗体 可变区的互补决定区与人抗体的互补决定区互换构成的 “人源化抗体”[27], 其靶点为 RSV 表面的 F 糖蛋白, 可干扰 F 糖蛋白介导的 RSV 与细胞的膜融合过程 ${ }^{[28]}$. 在帕利珠出 现之前, RSV 疾病的预防依赖于一种叫作 RespiGam(或 RSV-IGIV)的多克隆血清制剂. 这种多克隆制剂的比活性 较低, 需要使用相对大剂量的血清抗体制剂. 帕利珠降低 了向婴儿提供治疗剂量所需的体积, 并通过避免混合血清 的副作用改善了 RSV 的治疗 ${ }^{[29]}$.

2002 年, 阿达木(Adalimumab)出现, 它是全球首个全 人源化单抗，用于治疗类风湿性关节炎(rheumatoid arthri- tis, RA). 阿达木的靶点为肿瘤坏死因子 TNF- $\alpha^{[30,31]}$. 研究 发现，促炎细胞因子 TNF- $\alpha$ 、 IL- 1 和 IL- 6 的过度产生是导 致关节滑膜慢性炎症的关键因素，而阻断 TNF- $\alpha$ 即可明显 缓解整个炎症反应 ${ }^{[32]}$. 在阿达木单抗的全人源化过程中, 噬菌体展示抗体文库技术发挥着重要的支持作用. 利用噬 菌体展示的巨大的抗体组合库, 研究人员对抗 TNF- $\alpha$ 的动 物抗体进行改造, 实现了对抗 TNF- $\alpha$ 抗体的全人源化 ${ }^{[33]}$.

利妥昔、帕利珠和阿达木等代表性单抗在自身免疫病、 病毒性疾病和癌症治疗方面的成功应用是对市场的极大 鼓舞. 伴随着新技术的发展与广阔的市场需求空间，单抗 药物迎来了蓬勃发展的时期.

\section{2 抗肿瘤单克隆抗体药物的发展}

抗肿瘤单克隆抗体药物根据靶点可以分为直接靶向 肿瘤抗原与靶向免疫抑制分子两大类. 前者的代表药物是 1998 年基因泰克(Genetech)公司上市的曲妥珠(Herceptin). 曲妥珠靶向人表皮生长因子受体家族成员 HER2(human epidermal growth factor receptor-2), 被用于治疗 HER2 阳性 的乳腺癌. 其作用机理是通过阻断 HER2 信号通路, 抑制 肿瘤生长. 基因泰克公司另一种抗肿瘤单克隆抗体药物是 贝伐珠 (Bevacizumab), 它的靶点是血管内皮生长因子 (vascular endothelial growth factor, VEGF), 被用于治疗结 肠癌 ${ }^{[34]}$. 贝伐珠可特异性结合 VEGF, 抑制其刺激细胞膜 上的 VEGF 受体和肿瘤血管生成，从而抑制肿瘤生长 ${ }^{[35]}$.

免疫检查点(immune checkpoint)分子是抗肿瘤免疫发 挥负性调节的因子. 代表性的有细胞毒性 $\mathrm{T}$ 淋巴细胞抗原4(cytotoxic T lymphocyte antigen-4, CTLA-4)和程序性细胞 死亡受体-1 及其配体 (programmed death 1/programmed death ligand 1, PD-1/PD-L1)等. 伊匹木(Ipilimumab)是一种 CTLA-4 的人源单克隆抗体, 也是第一种被批准的免疫检 查点抑制剂. 最初的研究认为, CTLA-4 通过阻断 $\mathrm{T}$ 细胞共 刺激分子 $\mathrm{CD} 28$ 与抗原递呈细胞的 CD80 和 CD86 结合, 从 而抑制 $\mathrm{T}$ 细胞活化 ${ }^{[36]}$, 其抗体可抑制该结合作用，从而增 强 T 淋巴细胞的杀伤功能. 2011 年 3 月, 伊匹木被 FDA 批 准用于治疗晚期黑色素瘤 ${ }^{[37]}$. 近期的研究认为, 该抗体是 通过清除 Treg 细胞来解除对肿瘤的免疫抑制 ${ }^{[38]}$. PD-1 也 是 B7/CD28 共刺激受体家族的成员. PD-1 结合其配体 PD-L1 ${ }^{[39]}$ 可诱发细胞凋亡, 使得 $\mathrm{T}$ 淋巴细胞增殖得到抑制, 从而维持自身免疫平衡. 肿瘤细胞可高表达 PD-L1, 抑制 $\mathrm{T}$ 细胞的活化和增殖, 实现免疫逃逸 ${ }^{[00 ~ 43]} .2005$ 年, 研究 人员发现抗体阻断 PD-L1 或者 PD-1 途径均可以提高抗肿 瘤免疫反应 ${ }^{[44]} .2012$ 年, 抗 PD-1 抗体首次临床试验结果发 表 ${ }^{[45]} .2014$ 年, 首个抗 PD-1 单克隆抗体药物派姆(Pembrolizumab)上市, 作为高表达 PD-L1 肺癌的一线治疗药物 ${ }^{[46]}$. 目前, 已有 5 种抗 PD-1/PD-L1 类单克隆抗体药物上市, 被 广泛用于肺癌、黑色素瘤、乳腺癌、淋巴瘤、头颈癌等的 
治疗 ${ }^{[47]} .2013$ 年, 肿瘤免疫疗法被 Science 评为当年的科学 突破之首 ${ }^{[48]} .2018$ 年, 阻断 CTLA-4 与 PD-1 通路的肿瘤免 疫疗法荣获该年的诺贝尔生理学或医学奖.

\section{3 抗感染单克隆抗体药物的发展}

随着单个 $\mathrm{B}$ 细胞抗体克隆技术的发展, 越来越多的对 抗病原体的单克隆抗体被从感染过相关疾病或者接种过 疫苗的人体中分离得到, 为治疗 HIV 、埃博拉等感染性疾 病带来了希望. 其中, HIV-1 的广谱中和抗体(bnAbs)是从 一些 HIV 感染后能长期保存低病毒血症的 “精英患 者”,(elite controller)的 PBMC 中分离得到, 能结合 HIV 病毒 上与感染相关抗原上的保守表位. 典型的代表有 VRC01, 其中和表位是 HIV-1 表面 gp120蛋白上的 CD4 分子结合位 点, 可干扰 HIV-1 对 $\mathrm{CD} 4^{+} \mathrm{T}$ 淋巴细胞的识别. 另外一个 $\mathrm{bnAb}$ 10-1074 的中和表位是以 gp120 蛋白 V3 上高度保守 的 N332 糖基, 以及 V3 基部氨基酸和邻近糖基组成的构象 性表位. 这个抗体中和 HIV-1 的详细机制仍未知, 但可能 与抗体结合 Env 后阻碍 Env 与 CD4 分子的结合有关 ${ }^{[49,50]}$. 在 2015 2017 年, 初步临床试验结果显示, 注射这些 bnAbs 的患者都出现了明显的病毒血症被抑制的现象, 且 抗体的安全性良好 ${ }^{[51,52]}$.

除了慢性感染, 单克隆抗体药物在突发性传染病治疗 中的作用也受到了越来越多的重视. 2019 年 5 和 9 月, FDA 分别将孤儿药资格(orphan drug designation, ODD)和突破性 药物资格(breakthrough therapy designation, BTD)授予给了
一种可用于治疗埃博拉感染的单抗一mAb114. 这株单抗 是从一名埃博拉感染幸存者体内分离得到的. mAb114 的中 和位点为埃博拉病毒表面包膜糖蛋白 (glycoprotein, GP)上的 受体结合区域, 可阻碍 GP 介导的病毒与靶细胞的受体识别 与内吞过程 ${ }^{[53]}$, 在体外研究中可介导 ADCC, 并且能够保护 至少感染埃博拉病毒 $5 \mathrm{~d}$ 的非人类灵长动物 ${ }^{[54,55]}$. 在 2018 年伊始的临床三期研究中 ${ }^{[56]}$, 研究人员发现, mAb114 和另 外一种单抗混合物 REGN-EB3 能显著降低 $28 \mathrm{~d}$ 的病死率. 同时, 接受 mAb114 和 REGN-EB3 治疗的埃博拉病毒感染 的早期患者, 最高生存率可达 $90 \% .2018$ 年, N Engl J Med 发 表文章 ${ }^{[57]}$ 回顾了抗体在感染性疾病中的应用, 指出利用先 进抗体相关领域的研究进展，促进快速、有策略地开发单克 隆抗体, 将为防治日益严重的感染性疾病威胁提供重要技 术支撑, 最终可能改变传染病流行进程.

\section{4 总结与展望}

综上, 单克隆抗体技术的出现和应用离不开科学认知 的进步和技术革新的支持. 在基础研究方面, 结构生物学 不断的进步使人们可以在近原子层面观测抗原抗体互作 的相关规律; 从有限基因组产生无限抗体多样性的分子机 理和规律也正逐步被揭开神秘面纱. 现如今, 基因编辑技 术的飞速发展使得研究者们能够“定向、定点”改造生物分 子, 针对单克隆抗体药物进行精确改造将满足人们对疾病 诊疗需求. 有理由相信, 单克隆抗体技术和药物在未来仍 将为科学研究和人类健康发展带来新的推动和突破.

\section{推葆阅读文献}

1 Kohler G, Milstein C. Continuous cultures of fused cells secreting antibody of predefined specificity. Nature, 1975, 256: 495-497

2 von Behring E K S. Use of human immunoglobulins as an anti-infective treatment. Dtsch Med Wochenschr, 1890, 49: 1113-1114

3 Forthal D N. Functions of Antibodies. Microbiol Spectr, 2014, 2: 1-17

4 Kohler G, Milstein C. Derivation of specific antibody-producing tissue-culture and tumor lines by cell-fusion. Eur J Immunol, 1976, 6: $511-519$

5 Weiner L M, Surana R, Wang S. Monoclonal antibodies: Versatile platforms for cancer immunotherapy. Nat Rev Immunol, 2010, 10: 317-327

6 Huse W D, Sastry L, Iverson S A, et al. Generation of a large combinatorial library of the immunoglobulin repertoire in phage-lambda. Science, 1989, 246: 1275-1281

7 Powers A. Nobel Prize In Chemistry 2018: Using the principles of evolution to design novel chemical molecules. Retrieved Oct 27, 2018, https://www.forbes.com/sites/annapowers/2018/10/03/noble-prize-in-chemistry-2018-using-the-principles-of-evolution-to-design-novel-c hemical-molecules/\#4810697832cc

8 Boder E T, Wittrup K D. Yeast surface display for screening combinatorial polypeptide libraries. Nat Biotechnol, 1997, 15: 553-557

9 Bradbury A R, Marks J D. Antibodies from phage antibody libraries. J Immunol Methods, 2004, 290: 29-49

10 Ho M, Nagata S, Pastan I. Isolation of anti-CD22 Fv with high affinity by Fv display on human cells. Proc Natl Acad Sci USA, 2006, 103: 9637-9642

11 Kondo A, Ueda M. Yeast cell-surface display-Applications of molecular display. Appl Microbiol Biotechnol, 2004, 64: 28-40

12 Hanes J, Plückthun A. In vitro selection and evolution of functional proteins by using ribosome display. Proc Natl Acad Sci USA, 1997, 94: 4937-4942

13 Chin S E, Ferraro F, Groves M, et al. Isolation of high-affinity, neutralizing anti-idiotype antibodies by phage and ribosome display for application in immunogenicity and pharmacokinetic analyses. J Immunol Methods, 2015, 416: 49-58 
14 Tiller T, Meffre E, Yurasov S, et al. Efficient generation of monoclonal antibodies from single human B cells by single cell RT-PCR and expression vector cloning. J Immunol Methods, 2008, 329: 112-124

15 Ogunniyi A O, Story C M, Papa E, et al. Screening individual hybridomas by micro-engraving to discover monoclonal antibodies. Nat Protoc, 2009, 4: 767-782

16 Jin A, Ozawa T, Tajiri K, et al. A rapid and efficient single-cell manipulation method for screening antigen-specific antibody-secreting cells from human peripheral blood. Nat Med, 2009, 15: 1088-1092

17 Akkina R. Humanized mice for studying human immune responses and generating human monoclonal antibodies. Microbiol Spectr, 2014, doi: 10.1128/microbiolspec.AID-0003-2012

18 Carter P J. Potent antibody therapeutics by design. Nat Rev Immunol, 2006, 6: 343-357

19 Wege A K. Humanized mouse models for the preclinical assessment of cancer immunotherapy. Biodrugs, 2018, 32: 245-266

20 Green L L. Antibody engineering via genetic engineering of the mouse: Xeno-Mouse strains are a vehicle for the facile generation of therapeutic human monoclonal antibodies. J Immunol Methods, 1999, 231: 11-23

21 Lonberg N. Human antibodies from transgenic animals. Nat Biotechnol, 2005, 23: 1117-1125

22 Lu R M, Hwang Y C, Liu I J, et al. Development of therapeutic antibodies for the treatment of diseases. J Biomed Sci, 2020, doi: 10.1186/s12929-019-0592-Z

23 Sgro C. Side-effects of a monoclonal antibody, muromonab CD3/orthoclone OKT3: Bibliographic review. Toxicology, 1995, 105: 23-29

24 Smith S L. Ten years of orthoclone OKT3 (muromonab-CD3): A review. J Transpl Coord, 1996, 6: 109-119; quiz 120-101

25 Maloney D G, Grillo-Lopez A J, White C A, et al. IDEC-C2B8 (Rituximab) anti-CD20 monoclonal antibody therapy in patients with relapsed low-grade non-Hodgkin's lymphoma. Blood, 1997, 90: 2188-2195

26 Anderson K C, Bates M P, Slaughenhoupt B L, et al. Expression of human B cell-associated antigens on leukemias and lymphomas: A model of human B cell differentiation. Blood, 1984, 63: 1424-1433

27 Johnson S, Oliver C, Prince G A, et al. Development of a humanized monoclonal antibody (MEDI-493) with potent in vitro and in vivo activity against respiratory syncytial virus. J Infect Dis, 1997, 176: 1215-1224

28 Beeler J A, Coelingh K V. Neutralization epitopes of the F-glycoprotein of respiratory syncytial virus-Effect of mutation upon fusion function. J Virol, 1989, 63: 2941-2950

29 Both L, Banyard A C, van Dolleweerd C, et al. Monoclonal antibodies for prophylactic and therapeutic use against viral infections. Vaccine, 2013, 31: 1553-1559

30 Feldmann M M R N. Discovery of TNF- $\alpha$ as a therapeutic target in rheumatoid arthritis: Preclinical and clinical studies. Joint Bone Spine, 2002, 69: 12-18

31 Bain B, Brazil M. Adalimumab. Nat Rev Drug Discov, 2003, 2: 693-694

32 Feldmann M. Development of anti-TNF therapy for rheumatoid arthritis. Nat Rev Immunol, 2002, 2: 364-371

33 Jespers L R A, Mahler S M, et al. Guiding the selection of human antibodies from phage display repertoires to a single epitope of an antigen. Nat Biotechnol, 1994, 12: 899-903

34 Hurwitz H, Fehrenbacher L, Novotny W, et al. Bevacizumab plus irinotecan, fluorouracil, and leucovorin for metastatic colorectal cancer. N Engl J Med, 2004, 350: 2335-2342

35 Jain R K. Normalization of tumor vasculature: An emerging concept in antiangiogenic therapy. Science, 2005, 307: 58-62

36 Leach D R, Krummel M F, Allison J P. Enhancement of antitumor immunity by CTLA-4 blockade. Science, 1996, 271: 1734-1736

37 Hodi F S, O'Day S J, McDermott D F, et al. Improved survival with ipilimumab in patients with metastatic melanoma. N Engl J Med, 2010, 363: 711-723

38 Du X X, Tang F, Liu M Y, et al. A reappraisal of CTLA-4 checkpoint blockade in cancer immunotherapy. Cell Res, 2018, 28: 416-432

39 Latchman Y, Wood C, Chemova T, et al. PD-L2, a novel B7 homologue, is a second ligand for PD-1 and inhibits T cell activation. Faseb J, 2001, 15: A345-A345

40 Ishida Y, Agata Y, Shibahara K, et al. Induced expression of PD-1, a novel member of the immunoglobulin gene superfamily, upon programmed cell-death. EMBO J, 1992, 11: 3887-3895

41 Dong H D, Zhu G F, Tamada K, et al. B7-H1, a third member of the B7 family, co-stimulates T-cell proliferation and interleukin-10 secretion. Nat Med, 1999, 5: 1365-1369

42 Nishimura $\mathrm{H}$, Nose M, Hiai $\mathrm{H}$, et al. Development of lupus-like autoimmune diseases by disruption of the PD-1 gene encoding an ITIM motif-carrying immunoreceptor. Immunity, 1999, 11: 141-151

43 Freeman G J, Long A J, Iwai Y, et al. Engagement of the PD-1 immunoinhibitory receptor by a novel B7 family member leads to negative regulation of lymphocyte activation. J Exp Med, 2000, 192: 1027-1034 
44 Hirano F, Kaneko K, Tamura H, et al. Blockade of B7-H1 and PD-1 by monoclonal antibodies potentiates cancer therapeutic immunity. Cancer Res, 2005, 65: 1089-1096

45 Topalian S L, Hodi F S, Brahmer J R, et al. Safety, activity, and immune correlates of anti-PD-1 antibody in cancer. N Engl J Med, 2012, 366: 2443-2454

46 Reck M, Rodriguez-Abreu D, Robinson A G, et al. Pembrolizumab versus chemotherapy for PD-L1-positive non-small-cell lung cancer. N Engl J Med, 2016, 375: 1823-1833

47 Gong J, Chehrazi-Raffle A, Reddi S, et al. Development of PD-1 and PD-L1 inhibitors as a form of cancer immunotherapy: A comprehensive review of registration trials and future considerations. J Immunother Cancer, 2018, 6: 8

48 Couzin-Frankel J. Breakthrough of the year 2013. Cancer immunotherapy. Science, 2013, 342: 1432-1433

49 Zhou T, Georgiev I, Wu X, et al. Structural basis for broad and potent neutralization of HIV-1 by antibody VRC01. Science, 2010, 329: $811-817$

50 Julien J P, Sok D, Khayat R, et al. Broadly neutralizing antibody PGT121 allosterically modulates CD4 binding via recognition of the HIV-1 gp120 V3 base and multiple surrounding glycans. PLoS Pathog, 2013, 9: e1003342

51 Haynes B F, Burton D R, Mascola J R. Multiple roles for HIV broadly neutralizing antibodies. Sci Trans1 Med, 2019, 11: eaaz2686

52 Caskey M, Klein F, Nussenzweig M C. Broadly neutralizing anti-HIV-1 monoclonal antibodies in the clinic. Nat Med, 2019, 25: 547-553

53 Wang H, Shi Y, Song J, et al. Ebola viral glycoprotein bound to its endosomal receptor niemann-pick C1. Cell, 2016, 164: 258-268

54 Corti D, Misasi J, Mulangu S, et al. Protective monotherapy against lethal Ebola virus infection by a potently neutralizing antibody. Science, 2016, 351: 1339-1342

55 Misasi J, Gilman M S A, Kanekiyo M, et al. Structural and molecular basis for Ebola virus neutralization by protective human antibodies. Science, 2016, 351: 1343-1346

56 Mulangu S, Dodd L E, Davey R T, et al. A randomized, controlled trial of Ebola virus disease therapeutics. N Engl J Med, 2019, 381: 2293-2303

57 Marston H D, Paules C I, Fauci A S. Monoclonal antibodies for emerging infectious diseases-Borrowing from history. N Engl J Med, 2018, 378: 1469-1472 


\title{
Summary for “单克隆抗体的出现与发展”
}

\section{Advent and rise of monoclonal antibodies}

\author{
Xuejing $\mathrm{Ma}^{1 \dagger}$, Runhan $\mathrm{Li}^{1 \dagger}$ \& Baidong Hou ${ }^{1,2^{*}}$ \\ ${ }^{1}$ College of Life Sciences, University of Chinese Academy of Sciences, Beijing 100049, China; \\ ${ }^{2}$ The Key Laboratory of Infection and Immunity, Institute of Biophysics, Chinese Academy of Sciences, Beijing 100101, China \\ $\dagger$ Equally contributed to this work \\ * Corresponding author, E-mail: baidong_hou@ibp.ac.cn
}

Antibody is naturally evolved, highly specific immune molecules that recognize and eliminate pathogenic and disease antigens. Since its discovery, antibody has been widely used in clinics for the treatment of infectious diseases or as diagnostic tools. However, due to the polyclonal nature of serum antibody and the inconsistency of antibody titers, the efficacy of antibody therapies was severely compromised. Moreover, the potential hazards of anaphylaxis and the transmission of undetected blood-borne pathogens further hampered the clinical use of serum antibody.

In 1975, a Nature paper by Georges Kohler and César Milstein reported how to generate monoclonal antibodies (mAb) with the hybridoma technology. This ground-breaking discovery not only provided experimental evidence for the clonal selection theory of lymphocyte development, but also made it possible to produce a large amount of antibody with highly defined antigen specificity, which formed the basis for the future clinical applications that led to the tremendous successes of $\mathrm{mAb}$ therapies in the last three decades.

In honor of this important historical event in scientific discovery, we present a historical overview and summary of $\mathrm{mAb}$ development and clinical use. First, we briefly introduce the history of how the original mouse hybridoma technologies were developed. Next, we highlight two major technique advancements of $\mathrm{mAb}$ in the past forty-five years. The first is about the various techniques that can help in massive screening for mAb, such as those based on antibody display techniques using phage, yeast, mammalian cells, or ribosome, as well as the more recent single-cell techniques to obtain antibody genes directly from human blood cells or other samples. The second is about the techniques to develop humanized $\mathrm{mAb}$, as well as the techniques to directly generate $\mathrm{mAb}$ of human origin using novel tools such as transgenic mice that harbor part of the human immunoglobulin genes and can develop lymphocytes express human antibodies. Last, this review focuses on the development of mAb drugs for clinic therapies. Exemplary cases are provided to illustrate the effort to develop the first successful mAb drug for human therapy and the gradual evolution of mAb drugs from murine to human origin. Moreover, mAb therapies for malignant tumors, the arguably most promising direction of mAb drug development, including the mAb targeting the immune checkpoints are discussed. In light of the recent outbreak of the COVID-19 pandemic and the heated search for effective treatment, the development of mAb drugs for treating infectious diseases such as HIV and Ebola are also discussed. We believe these successes of mAb therapies herald an era in which the commercial development of $\mathrm{mAb}$ will continue to make even greater achievement.

monoclonal antibody, hybridoma technology, antibody engineer, antibody therapy

doi: $10.1360 /$ TB-2020-0492 